ISSUE BRIEF

\title{
Due Diligence and Stewardship in a Time of Change and Uncertainty
}

April 26, 2016

Deanna Marcum
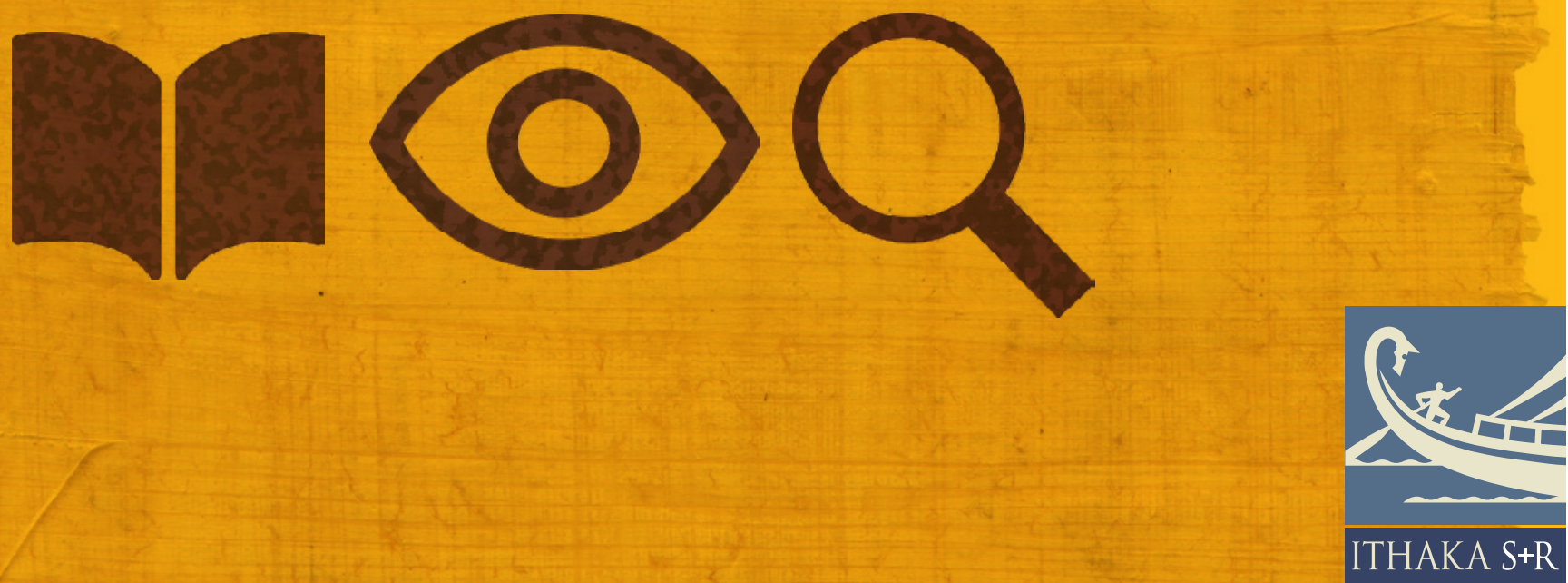


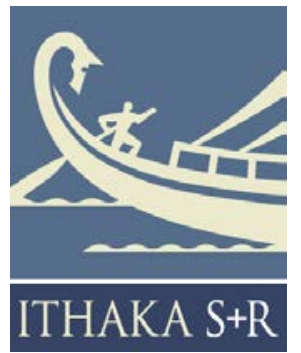

Ithaka $\mathrm{S}+\mathrm{R}$ is a strategic consulting and research service provided by ITHAKA, a not-for-profit organization dedicated to helping the academic community use digital technologies to preserve the scholarly record and to advance research and teaching in sustainable ways. Ithaka $\mathrm{S}+\mathrm{R}$ focuses on the transformation of scholarship and teaching in an online environment, with the goal of identifying the critical issues facing our community and acting as a catalyst for change. J STOR, a research and learning platform, and Portico, a digital preservation service, are also part of ITHAKA.
Copyright 2016 ITHAKA. This work is licensed under a Creative Commons Attribution-NonCommercial 4.0 International License. To view a copy of the license, please see http://creativecommons.org/licenses/by-nc/4.0/.

ITHAKA is interested in disseminating this brief as widely as possible. Please contact us with any questions about using the report: research@ithaka.org. 
This Issue Brief has been adapted from Deanna Marcum's keynote address at the CRL Collections Forum held in Chicago on April 14, 2016. ${ }^{1}$

For as long as humankind has been recording thoughts and ideas, we have been concerned about the technologies and processes that will ensure preservation of those records. Consider Cassiodorus, a high official in the Ostrogothic Kingdom in Italy in the Sixth Century, AD, who wrote about the invention of papyrus with all of the enthusiasm we associate with computer scientists who write about digital media. In English translation, this is how Cassiodorus described papyrus:

Then was papyrus invented, and therewith was eloquence made possible. Papyrus, so smooth and continuous, the snowy entrails of a green herb; papyrus which can be spread out to such a vast extent, and yet be folded up into so little space; papyrus, on which white expanse the black characters look beautiful; papyrus which keeps the sweet harvest of the mind and restores it to the reader whenever he chooses to consult it; papyrus which is the faithful witness of all human actions, eloquent of the past, a sworn foe of oblivion. ${ }^{2}$

In the United States, we librarians were consumed for the first couple of centuries by building collections. Along with the explosive growth that occurred in the post-World War II years, we also began thinking about what technologies and processes would ensure that these materials we were gathering would be available for the long term. What tools and media would we use to guard against oblivion?

For centuries, paper seemed to be the answer, but paper manufacturing processes that began in the Civil War era produced acidic paper, and by the 1960s evidence of our crumbling collections could not be ignored. The Association of Research Libraries (ARL) took note of the research the Barrows Laboratory of the State Library of Virginia had conducted in the late 1950s about the catastrophic consequences of acidic paper, and the largest libraries felt the urgency in addressing the problems before their book collections turned to dust. What could they do about the ticking time bomb in their stacks? The ARL library directors wondered if they should commit to using the $20^{\text {th }}$ century equivalent of papyrus-microfilm—to save their collections.

\footnotetext{
${ }^{1}$ The full program, list of speakers, and recordings of the first day presentations can be found at https://www.crl.edu/node/11968.

2 Ernst Posner, Archives in the Ancient World (Chicago: Society of American Archivists, 2003), 186. Reissue of the 1972 original, which modified the English translation from Thomas Hodgkin, ed., The Letters of Cassiodorus (London, 1886).
} 
With financial support from the Council on Library Resources, ARL commissioned a study - to be carried out by the Center for Research Libraries' director Gordon Williams-on how to deal with the preservation problem. In 1964, Williams reported his results: the technology (microfilm) had problems; micro blemishes had been detected. Instead of microfilming the collections, he proposed a central repository agency that would save one original copy of significant books. For those that were already in a state of deterioration, he recommended a combination of deacidification and cold storage. Copies would be made in case there was a need to use the scholarly work that was housed in the central repository.

Williams' plan was endorsed by ARL in 1965 and adopted as an action plan by the Library of Congress. You will not be surprised to hear that technical, administrative, and fiscal problems stopped the plan in its tracks.

The awareness of the preservation problem continued to grow, however, and the large research libraries continued to discuss solutions.

Perhaps, the Library of Congress could solve the problem; after all, the library world still looked at the Library of Congress as the country's preservation leader. Since the early 1900s, preservation had been highlighted as a priority of the national library. By 1923, preservation claimed 60 staff members (some on assignment at the GPO to do printing and binding). Archibald MacLeish, appointed Librarian of Congress in the early 1940s, appointed a Keeper of the Collections Maintenance and Preservation. In the 1960s, Librarian of Congress L. Quincy Mumford bolstered the preservation commitment by establishing a national preservation program that included a preservation lab. In 1967, Frazer Poole was appointed to organize and develop a comprehensive preservation program that would serve the country. And when Daniel Boorstin was appointed Librarian of Congress in 1975, one of his earliest acts was to convene a distinguished group of scholars and librarians to develop a National Preservation Program.

Research libraries appreciated these efforts by the Library of Congress, but they remained worried about their own collections, too. Warren J. Haas, University Librarian at Columbia, and the elected president of ARL, made preservation a priority and wrote a report, issued in 1972 that called for collaborative action in four areas: ${ }^{3}$

${ }^{3}$ Warren J. Haas, Preparation of Detailed Specifications for a National System for the Preservation of Library Materials: Final Report (Washington DC: Association of Research Libraries, 1972), http://www.worldcat.org/title/preparation-ofdetailed-specifications-for-a-national-system-for-the-preservation-of-library-materials-finalreport/oclc/781585?referer=di\&ht=edition. 
1. Research on deacidification and optimal storage conditions

2. Education and training in preservation and conservation

3. Individual libraries supporting their own preservation programs

4. Collective action to establish a nation preservation collection that would be located in several libraries or locations, but would be specially designated as a national preservation collection

It is on this last recommendation that I want to pause for a moment. What J im Haas was signaling with this recommendation is that a handful of the largest research libraries were shouldering the preservation burden, and if this was to continue, they needed to have some kind of financial support for serving in that role.

The largest research libraries (primarily Harvard, Yale, Princeton, Columbia, New York Public Library, and the Library of Congress), at least until recently, have been libraries of record and considered it their obligation to preserve those collections. But they have not been able to take on the fiscal burden of preservation for the entire country. It is quite understandable that they have searched for collaborative solutions that would result in a national system.

All of these representatives took part in the Library of Congress's planning meeting for the National Preservation Program, where Daniel Boorstin said, "We are here to preserve civilization. Preservation is the great forgotten problem of our age." With these words, Boorstin opened the conference at the Library of Congress on December 16, 1976. The group of 50 distinguished participants were motivated by this call to action:

"If the preservation problem, the brittle books problem, is one of cataclysmic proportions, it does offer us an opportunity of cataclysmic grandeur, to save the record of our civilization, past and future. It is the duty of the Library of Congress to take the leadership in this undertaking -in a collaborative spirit, appropriate to an institution of collaboration, cooperation and compromise."4

In case you have been counting, yes, this is the third time that the Library of Congress had announced a national preservation plan. The Library was well aware of the growing problem, as were other large research libraries. The Library of Congress estimated that six million of its 17 million volumes were in an advanced state of deterioration. The New York Public Library was in worse condition: $50 \%$ of its collections were beginning to crumble.

${ }^{4}$ The Republic of Letters: Librarian of Congress Daniel J. Boorstin on Books, Reading, and Libraries, 1975-1987, ed. John

Y. Cole (Washington DC: Library of Congress, 1989), 31. 
Jim Haas, scribe for the meeting's proceedings, summarized with this declaration:

"Scholars, librarians, and archivists do, in fact, have the responsibility to solve the preservation problem. And that responsibility is not conditional and it does not depend on public perception, or amount of money, or anything else. It is our responsibility and we either succeed or fail. The rate at which things get done is a function of money; whether or not they get done is a function of people....What we also must do is develop a national capacity that will provide us with options among which individuals, acting in their professional capacities, can choose."

Despite the gravitas of the meeting, the planning conference for a National Preservation Plan went nowhere. There was too much debate about a centralized agency versus a distributed effort.

Fast forward to the 1980s when the Council on Library Resources concluded that the Library of Congress was not going to take action and renewed its efforts in preservation. $\mathrm{J}$ im Haas, who was by this time the president of CLR, established a Committee on Preservation and Access in the fall of 1984. Again, a distinguished group of librarians, scholars, and administrators was assembled to develop a realistic plan to tackle the brittle books problem. The group immediately wanted more data. Dean Robert Hayes of UCLA was hired to look at the data growing out of the preservation assessments that had been conducted by the Library of Congress, the New York Public Library, Stanford, and Yale Universities to determine the magnitude of the problem. He calculated that in ARL libraries (then having a collective 305 million volumes), approximately 75 million volumes were at risk of deterioration. He then subtracted the preservation work that had already been done by individual libraries and factored in the overlap between collections, and estimated that the preservation problem could be mitigated by microfilming 3.3 million volumes at a cost of $\$ 384$ million over the next 20 years.

With these data in the background, the Committee on Preservation and Access reached six fundamental conclusions: ${ }^{5}$

1. Preservation and access are two sides of a coin. Their first principle was that access is the corollary of preservation.

2. Knowing the magnitude of the problem in specific terms allowed them to articulate with precision what needed to be done.

${ }^{5}$ Brittle Books. Reports of the Committee on Preservation and Access (Washington DC: Council on Library Resources, 1984). 
3. The work must necessarily be collaborative. Research libraries and their universities needed to understand that they are part of the "national" collection.

4. Microfilming was judged to be the most reliable technique for saving material, even though there was a great interest in video and optical disk technology in the community.

5. Preservation must not be thought of as a library problem but as a problem to be generally understood by those who use and fund libraries.

6. The magnitude of the problem called for a systematic approach, broken down into a series of steps required to achieve the plan.

The Committee continued its work through 1986, convening two larger forums to report on progress along the way. The committee called for a fully-funded, fully-staffed Commission on Preservation and Access. The Commission was to:

1. Develop a funding plan for the preservation of brittle books and to develop a program to generate funds for use by participating libraries

2. Establish a governance structure for carrying out the work

3. Promote further development of a preservation information service by the Library of Congress

4. Encourage technical and other research on topics of importance to the brittle books program

5. Establish a system to monitor progress

6. Monitor the performance of bibliographic systems to assure that information required to manage the preservation enterprise was readily available

To avoid concerns about the small, centralized staff having so much control, the Committee also called for a National Advisory Council on Preservation. It was to be affiliated with the Library of Congress, and membership would include individuals designated by library, archival, academic, and scholarly organizations with an interest in preservation. Its purpose was to:

1. Inform members of their constituent organizations about preservation plans and operation

2. Bring to the Commission the interest, concerns, and advice of their members,

3. Work in collaboration with the Commission to develop procedures and activities required to support funding for preservation

4. With guidance form the Commission, participate in long-range policy review

5. Promote the objectives of preservation and conservation internationally

The excitement about the newly formed Commission on Preservation and Access, headed by Patricia Battin, formerly University Librarian at Columbia, only grew when the 
National Endowment for the Humanities established an Office of Preservation, which was charged with supporting a "sustained and coherent attack on the preservation problem." William Bennett, chairman of the NEH pledged \$20 million a year for the next 20 years to solve the preservation problem. Grant funding was made available to libraries pledging to microfilm important scholarly material and deposit a microfilm master with the Library of Congress and ensure that bibliographic records of the preservation copy were entered into both the RLIN and OCLC databases.

So what happened to the Commission? The library community was highly critical of the composition of the Commission itself. The absence of "real" preservation librarians on the Commission offended the preservation staff in research libraries. The Library of Congress did not fully embrace its role to lead the National Advisory Council, and although it existed in name, it was never a fully functioning body. William Bennett's term at NEH ended and his pledge was not honored by his successor Lynne Cheney. NEH's Office of Preservation continued to make grants to libraries to film brittle books, as its modest budget allowed. Meanwhile, the technology community was up in arms that microfilming was continuing when digitization was so obviously the right answer. The Commission on Preservation and Access established a group to study the benefits of digitization, but refused to reverse its decision to adopt microfilming as the correct technology.

I could say much more about the Commission on Preservation and Access, but I'll conclude this section by saying that in 1996, I completed the merger of the Council on Library Resources and the Commission on Preservation and Access into the Council on Library and Information Resources. Preservation continued as one of the major programs, but the Commission was disbanded and libraries everywhere were converting significant portions of their preservation budgets to digitization efforts. CLIR also established the Digital Library Federation, bringing together representatives of research libraries determined to create digital libraries, either separately or collectively. With a growing interest in digitization instead of microfilming, the Association of Research Libraries, an organization that had made preservation a priority from its beginning in the 1930s, disbanded its Preservation Committee in October 2005.

\section{Digital technology generated wild and wonderful aspirations among librarians.}

Digital technology generated wild and wonderful aspirations among librarians. The Library of Congress announced that it had in hand private and public funds to digitize a 
large portion of its primary source material and make it widely available to the public. First using CD-ROMs to distribute collections to schools and libraries when it was launched in the early 1990s, the American Memory project soon became a web-based resource available to the world. The Librarian of Congress referred to American Memory as the national digital library, but others in the library community resisted any notion of a central agency taking this position. Meanwhile, the Digital Library Federation became more resolute in its efforts to build a distributed national collection of digitized materials.

The idea for creating a digitized corpus of scholarly journals resulted in J STOR, a notfor-profit initiative funded initially by The Andrew W. Mellon Foundation in the early 2000s. ${ }^{6} \mathrm{~J} \mathrm{STOR}$ was conceived as a plan that would allow libraries to move print runs of journals out of their over-crowded stacks by making the contents electronically available. In the case of both American Memory and J STOR, it was evident that the ease and convenience of the digitized content was popular with users, and libraries everywhere tried to secure philanthropic funding to do their own digitization. There were, of course, the usual concerns about intellectual property rights and technical infrastructure needed for providing digital library services. But the biggest concern was preservation. How are these digital collections going to be preserved? The Library of Congress had its own preservation lab and made the decision that preservation of the original would be part of the workflow of adding material to the digital collection. J STOR's preservation issues were even harder. J STOR took a curatorial approach to back file digitization, but they did not include the preservation of born-digital materials such as electronic journals. Portico, a digital archiving service, was established with very different ingest requirements and scale economies. The funding model called for contributions from both the journal publishers who generated the content and the library community that needed assurance that a central agency would promise long-term digital preservation of resources they no longer owned. Over time, Portico has added e-books and digitized collections to the archives.

You will not be surprised to hear that the same divisive issues were raised by the library community. Can a third party be trusted? Why not do this work ourselves? There isn't enough money in library budgets to pay for preservation. Along with Portico, we now also have LOCKSS and CLOCKSS that pride themselves as being of, by, and for the library community. There are strong advocates for both approaches, but the unfortunate result is that for one format, there are two services, while there is still so much work to be done in preservation generally.

${ }^{6}$ For more on JSTOR's founding, see Roger C. Schonfeld, JSTOR: A History (Princeton: Princeton University Press, 2003). 
The Library of Congress also had concerns about preserving its digitized content as well as the born-digital materials that were arriving with increasing frequency. With federal funding, the Library created the National Digital Information Infrastructure and Preservation Program, infelicitously known as NDIIPP. Senator Ted Stevens pledged \$100 million over a period of several years, with key milestones being met, to solve digital preservation problems for the nation. The milestones were only partially met. The library community brought together to advise on the project could not agree on priorities. The same issues Daniel Boorstin had been concerned about a generation earlier-administrative, bureaucratic, and fiscal issues-were soon apparent, and Senator Stevens had an unhappy end to his Congressional career. In the midst of a financial crisis, Congress reclaimed the $\$ 47$ million that had not been spent, and the program came to an end.

Other players have made strong contributions to preservation, as well. The Internet Archive, established by Brewster Kahle in 1996, does not have a formal preservation program, but the digitized content of books, films, videos, and television, along with the results of massive web crawls, constitutes a freely accessible resource that is kept safe in three mirror sites, one of which is located in another country. The Hathi Trust is also preserving the digitized versions of books from the Google Book Project, and is also apparently launching a companion print preservation effort. The Center for Research Libraries in its early history had a strong microfilming program in place and continues to microfilm newspapers collected by the Library of Congress's overseas offices. More recently, it has assumed an important role of certifying and validating digital repositories. In even more recent history, we have seen the advent of the Digital Preservation Network (DPN), which advertise itself as "the only large-scale digital preservation service that is built to last beyond the life spans of individuals, technological systems, and organizations." By paying an annual fee based on size of the deposit, member institutions can deposit their digital collections for long-term preservation with content being replicated in multiple nodes of the system. DPN is also considered to bea service of, by and for the library community, with the added assurance of governance by academic administrators, technologists, and librarians.

\section{The need for a national preservation plan is more urgent} than ever.

So here we are in Chicago in 2016 considering due diligence and stewardship in a period of change and uncertainty. The world has become more complex. There are more 
demands on our shrinking library dollars. Expectations for digital access are ubiquitous and growing. And the need for a national preservation plan is more urgent than ever.

I did not tell you this sad story only to amuse you. I have lived through nearly all of this history I have just recounted. With each new initiative, I have been hopeful that this is the one that will capture librarians' imaginations-that, finally, we are going to make real progress on ensuring that our intellectual and cultural record will be saved for future generations. I have been hopeful that we can put aside competitive feelings and work on a plan that will allow all preservation contributions to add up to something. In the print world, most libraries could sit out the preservation dance, knowing that a few of the very large libraries would make every effort to preserve their books and journals. In the digital world, every library is involved. No library owns the content they count on for their scholars and students. Every single institution has a stake in preserving digital content.

We must find a way to get behind a national preservation plan. To do nothing means a lot of hand-wringing in public while a generation of knowledge is vulnerable to permanent loss. We have learned valuable, if negative, lessons. We have learned that government agencies rarely deliver all that we hope for. We have learned that selfselected groups simply annoy others. In my view we have also learned that initiatives that have been the brainstorm of an individual rarely last beyond that champion. Perhaps it is time to consider an elected body with representatives from many different sectors who can come together and create a plan that builds on all of the good work now going on but knits it together so that it adds up to "saving our civilization."

Americans pride themselves on individual efforts. But we are running out of time. A new Librarian of Congress will soon, I trust, be confirmed. Can we as a community put together a strong recommendation that the Library of Congress resume its role as preservation leader? Or is there another organization we can agree on to take the lead? Can Hathi Trust or CRL or the Internet Archive assume a leadership role on behalf of the community? Can we commit to doing our part by adding our individual efforts to the collective whole? Can we appoint a community-based oversight committee to ensure that all efforts go toward the one big goal of ensuring that knowledge created today will still be here tomorrow?

J im Haas's words still ring clear: "Scholars, librarians, and archivists do, in fact, have the responsibility to solve the preservation problem. And that responsibility is not conditional and it does not depend on public perception, or amount of money, or anything else. It is our responsibility and we either succeed or fail." 